\title{
English as a lingua franca: analyzing research frameworks in international English, world Englishes, and ELF
}

\begin{abstract}
ANNE PAKIR*
ABSTRACT: This paper considers the problems, the properties, and the prospects of using 'English as a lingua franca' as a construct and as a reality. It will therefore focus on what is meant by the term 'lingua franca', what is represented as a 'lingua franca', and what the debates are about English as a lingua franca. The point of departure is Kachru's description of English as a lingua franca as 'a communicative tool of immense power'. How this tool is used in the Outer Circle and elsewhere has been addressed elsewhere, but the discussion is an attempt to examine the issues in Singapore, where English has indeed become an international lingua franca as well as a national lingua franca for Singaporeans. The hope is that this paper will contribute to the ongoing dialog by asking questions rather than offering definitive answers to a very complex emergent phenomenon: the character and traits of English as a lingua franca in the 21 st century and the sociolinguistic realities of its existence.
\end{abstract}

\section{INTRODUCTION}

English as a lingua franca, however we define the term, has become a communicative tool of immense political, ideological, and economic power. (Kachru 1996: 910)

In this paper, we will be looking at the problems, the properties and the prospects of using 'English as a lingua franca' as a construct and as a reality. The discussion will therefore center on what is meant by the term 'lingua franca', what is represented as 'lingua franca', and what the debates are about English as a lingua franca. English as a lingua franca, as Kachru reminds us, is 'a communicative tool of immense power'. How this tool is used in the Outer Circle is a concern, and elsewhere (Pakir 2003: 21-32) I have attempted to examine the issues in Singapore, where English has indeed become an international as well as a national lingua franca.

My paper here will focus on what I deem to be happening in the three Kachruvian circles in terms of theoretical and ideological positions regarding English, and what English as a lingua franca might imply in terms of cultural and pedagogical developments for the different settings. It is hoped that this paper will help to raise questions rather than offer definitive answers to a very complex emergent phenomenon - that of the character and traits of English as a lingua franca in the 21 st century and sociolinguistic realities of its existence as a lingua franca.

Going beyond the politics and the economics of English as a lingua franca, and perhaps addressing only the views on the spread of English and the resulting consequences, I pose three questions.

\footnotetext{
*Department of English Language and Literature, National University of Singapore, 7 Arts Link, Block AS5, Kent Ridge, Singapore 117570. E-mail: ellannep@nus.edu.sg
} 
1. How is 'lingua franca' used as a construct within the framework of world Englishes?

2. How is 'lingua franca' used as a construct within the framework of ELF/LFE?

3. How different and alike are they compared to the construct of English as an International Language (EIL) inter alia, International English (IE)?

In the pursuit of some answers, we need to examine theory and research in the paradigms of English as an International Language (EIL) - which I shall equate in this paper to International English (IE) - and those of WE and ELF. An examination of the discourses surrounding these three concepts will highlight some differences and similarities as well as their cultural and pedagogical implications.

My particular focus is on the theory, research and pedagogy arising in the new contexts of using English as a World Language, even if it is assumed that all of us - language teachers and practitioners - have used, are using, and will continue using - much of the established works and findings by BANA (British-Australian-North American) researchers in the Inner Circle of English. The BANA axis of influence in English language teaching and methodology is certainly accepted as reality in the Outer and Expanding Circles, but it might be useful to look at emerging paradigms or movements for dealing with English in the 21 st century. For example, a close examination of these frameworks (IE, WE, and ELF) was useful for studying English as negotiated language in education in Singapore since the country presents a case study par excellence of a national and multilingual setting where English is heavily used as an international as well as an intra-national lingua franca.

In the next section, we focus on international English (IE), world Englishes (WE), and ELF (English as a lingua franca) as constructs, paradigms, or movements, and their implications. This section on the theory and research in different paradigms begins with the notion that these three currently hold sway in the study of English as a lingua franca for the world. The first is international English (IE) as discussed within Inner Circle of English and BANA communities and directing the current dominant ELT pedagogies. Trudgill and Hannah's (1995: 1) definition (updated in 2002) is generally accepted to represent IE, inter alia, standard English:

the variety of the English language which is normally employed in writing and normally spoken by 'educated' speakers of the language. It is also, of course [my italics], the variety of English that students as Foreign or Second Language (EFL/ESL) are taught when receiving formal instruction.

The second is world Englishes (WE), a label that is today accepted in the literature and adopted in all the three circles of English but especially within Outer Circle countries. But there exist some subtle distinctions to this label. As Bolton (2004: 367) notes, the term 'world Englishes' functions generally as 'an umbrella label' for all varieties of English worldwide (world English and international Englishes), but usually refers to 'new Englishes' (institutionalized ESL varieties, or nativized and indigenized varieties). However, within the discipline of applied linguistics, 'world Englishes' refers particularly to 'the wide-ranging approach to the study of the English language worldwide particularly associated with Braj B. Kachru and other scholars working in a "world Englishes paradigm"” (Bolton 2004: 367). The nativization of English in transplanted soil is a major linguistic claim of the adherents to this WE paradigm. We will take this body of scholarship as our reference point in the ensuing discussion. 
The third and newly emerging paradigm (earlier often referred to as a 'movement') is that of English as a lingua franca (ELF) or, more correctly, English lingua franca (ELF) or lingua franca English (LFE) as discussed in the Expanding Circle of English, with research and discussions currently led by European researchers such as Seidlhofer (2004). Scholars working with Seidlhofer have determined that the abbreviation or acronym ELF is the one they prefer to represent their formulation of 'English as a lingua franca'. This preference gives rise to a terminological difficulty in discussions of English as a lingua franca, for the general reference to a lingua franca has now been restricted to a particular reference for those working within the ELF framework.

'English as a lingua franca (ELF)' is, according to Seidlhofer, offering a definition of ELF in its purest form by citing Firth, 'a contact language between persons who share neither a common native tongue nor a common (national) culture, and for whom English is the chosen foreign language of communication' (Firth 1996, cited in Seidlhofer 2004: 211).

From my perspective, the established IE paradigm is being challenged in the $21 \mathrm{st}$ century by emerging and evolving paradigms (WE/ELF). This phenomenon displays rather effectively an 'old kid' versus 'new kids on the block' syndrome. Being the oldest, most established, and most widely accepted model, IE took a long time before admitting WE perspectives in discussions, or even recognizing WE as a viable approach to studying English in the world. WE in the 1980s (led by Kachru, who went on to establish the international refereed journal World Englishes, with co-editor Larry Smith) had to explain and establish itself as a new and emerging alternative to teaching and researching English as a language in the world. It was part of the process of differentiation and gaining recognition that ELF in this first decade of the 21 st century is currently undergoing.

\section{IE, WE, AND ELF: POINT OF DEPARTURE}

I will attempt to characterize the emerging and evolving paradigms vis-à-vis the old established one using as a point of departure the several views on the global spread of English and their implications as tabulated by Pennycook (2002: 222), I take a step furtherwith apologies to Pennycook, who did not categorize them into sets of views as seen from, for example, the IE paradigm or the WE paradigm. I have added a third set of views, from the ELF perspective. The first set of three (Table 1) clearly demonstrates an IE and/or BANA point of view.

A fourth view of the global spread of English listed by Pennycook is that of imperialism (Phillipson 1992), with the danger of homogenization and of destruction of other cultures

Table 1. ICE, IE and BANA points of view (apologies to Pennycook 2002)

\begin{tabular}{|c|c|c|}
\hline $\begin{array}{l}\text { View of the global } \\
\text { spread of English }\end{array}$ & $\begin{array}{l}\text { Implications for culture } \\
\text { and development }\end{array}$ & Pedagogical implications \\
\hline Colonial-celebratory & $\begin{array}{l}\text { English an inherently useful } \\
\text { language }\end{array}$ & $\begin{array}{l}\text { Teach English to those who can } \\
\text { appreciate it }\end{array}$ \\
\hline Modernization & $\begin{array}{l}\text { English a crucial tool for } \\
\text { modernization }\end{array}$ & $\begin{array}{l}\text { Teach English to modernize the } \\
\text { world }\end{array}$ \\
\hline Laissez-faire liberalism & $\begin{array}{l}\text { English a functional tool for } \\
\text { pragmatic purposes }\end{array}$ & $\begin{array}{l}\text { Business as usual: give people what } \\
\text { they want }\end{array}$ \\
\hline
\end{tabular}


Table 2. OCE and WE views (apologies to Pennycook 2002)

\begin{tabular}{llc}
\hline $\begin{array}{l}\text { View of the global } \\
\text { spread of English }\end{array}$ & $\begin{array}{l}\text { Implications for culture } \\
\text { and development }\end{array}$ & Pedagogical implications \\
\hline $\begin{array}{l}\text { Linguistic hybridity in } \\
\text { OCE }\end{array}$ & $\begin{array}{c}\text { Languages and cultures change and } \\
\text { adapt }\end{array}$ & $\begin{array}{c}\text { World Englishes, multiple } \\
\text { standards, assume change } \\
\text { Postcolonial performativity } \\
\text { in OCE }\end{array}$ \\
$\begin{array}{c}\text { Cultural politics of change, language, } \\
\text { knowledge and difference }\end{array}$ & $\begin{array}{c}\text { Critical language education for } \\
\text { struggle, appropriability }\end{array}$ \\
\hline
\end{tabular}

and languages, and where the pedagogical panacea would lie in focusing on language rights, instruction in mother tongues, protectionism. But I have omitted this, since it is not directly relevant to the discussion. The three views - colonial celebratory, modernization, and laissez-faire liberalism - suggest that the world's users of English desire and demand IE, the most effective form of this 'communicative tool of immense power'. Against the current backdrop of globalization and economic development in metropolitan centers and urbanized sectors in the 21st century, the assumption is that ICE (BANA) countries would provide leadership in 'teaching English' (the IE kind) and 'giving people what they want.'

However, an alternative set of views of the global spread of English is that found within the WE paradigm: linguistic hybridity and postcolonial performativity (see Table 2). These are views that seem to be readily appreciated by Outer Circle English (OCE) countries and their researchers.

The WE group of scholars influenced by the Kachruvian view of the pluricentricity of English over three main blocs of English users in the world has had to point out the limitations of the perspectives of those in the Inner Circle who espoused strongly ENL practices and approaches to the teaching of English (as ESL/EFL). Within the WE paradigm, a strongly argued new role for English is that of a reconfigurer of multiple cultures and identities, leading to world Englishes, each of which potentially carries an emergent status as a glocal language (Pakir 1997).

The scholars working in the ELF paradigm and starting about 20 years later after the emergence of WE studies are beginning to look at English differently again (Table 3).

Much of the debate within the newer camps - and indeed even of the earliest camp, the Inner Circle - centers on their interpretation of the role of English as a lingua franca. So, it might benefit us to examine the approaches, the champions, the objectives, and the research and practice within each of the three paradigms, as organized in the tables below. The questions to be asked include the following: Are these competing or complementary paradigms? Do we, against the 21 st-century English language teaching

Table 3. ELF view of the global spread of English

\begin{tabular}{lll}
\hline $\begin{array}{l}\text { View of the global } \\
\text { spread of English }\end{array}$ & $\begin{array}{l}\text { Implications for culture } \\
\text { and development }\end{array}$ & Pedagogical implications \\
\hline $\begin{array}{l}\text { Modern-day connectivity } \\
\text { in ECE }\end{array}$ & $\begin{array}{c}\text { English as a language of } \\
\text { communication in Expanding } \\
\text { Circle English (ECE): no } \\
\text { linguaculturae from Inner Circle } \\
\text { English (ICE) (IE-ENL) }\end{array}$ & $\begin{array}{c}\text { Languages and cultures in ECE } \\
\text { develop in their own right: } \\
\text { pluricentric Englishes can be } \\
\text { taught but with ELF core }\end{array}$ \\
& \\
\hline
\end{tabular}


Table 4. The IE paradigmatic axioms

\begin{tabular}{llll}
\hline Approach & Exponents & Objectives & Research and practice \\
\hline $\begin{array}{l}\text { (ELT/EFL) } \\
\begin{array}{c}\text { Focus: language } \\
\text { proficiency }\end{array}\end{array}$ & Prator/Quirk & $\begin{array}{c}\text { To teach established } \\
\text { varieties of English }\end{array}$ & $\begin{array}{c}\text { BANA-based curricula, } \\
\text { methodology, materials, } \\
\text { Bodies: TESOL, } \\
\text { IATEFL }\end{array}$ \\
\hline
\end{tabular}

and learning landscape, draw upon an eclectic use of the pedagogical implications, for instance?

In the IE paradigm (see Table 4), the focus is on language proficiency, learner deficiencies (and teaching accent reduction, for example) aided by institutional or professional organizations such as the Teaching of English to Speakers of Other Languages (TESOL) and the International Association for the Teaching of English as a Foreign Language (IATEFL). English is usually seen to be a 'foreign language' to the learners.

The WE paradigm offers working principles from an ELT/ESL perspective as seen in Table 5, with international organizations such as the International Association for World Englishes (IAWE) and specialized graduate schools such as the College of World Englishes at Chukyo University in Nagoya, Japan.

In the WE paradigm, features of new Englishes (e.g. phonological, syntactic, lexical) are often codified with some attention also to supra-features as found in discourse analysis, genre analysis, and pragmatics studies. The legitimization process for the new Englishes include exploring sociolinguistic realities, ideological underpinnings of learning English, and cultural dimensions of its use.

In the emerging ELF paradigm that has yet to establish itself wholly as a viable alternative to IE and WE, the focus so far has been on Expanding Circle users of English who use English with one another (Table 6).

WE and ELF are similar in that they have four common working axioms: emphasizing the pluricentricity of English, seeking variety recognition, accepting that language changes and adapts itself to new environments, and highlighting the discourse strategies of Englishknowing bilinguals.

WE and ELF differ in that, while WE includes all users of English in the three circles, ELF does not, choosing instead to focus on ECE users, who have no language in common and thus choose English as the default language.

Table 5. The WE paradigmatic axioms

\begin{tabular}{|c|c|c|c|}
\hline Approach & Exponents & Objectives & Research and practice \\
\hline $\begin{array}{l}\text { (ELT/ESL-EFL) } \\
\text { Focus: sociolinguistic } \\
\text { realities } \\
\text { Bodies: IAWE, College } \\
\text { of World Englishes }\end{array}$ & $\begin{array}{l}\text { Kachru (e.g. 1982; } \\
\text { 1983; 1986; 1996); } \\
\text { Smith (1981; 1988); } \\
\text { Lowenberg (1984); } \\
\text { Pakir (1994; 1997); } \\
\text { Bautista (1997) }\end{array}$ & $\begin{array}{l}\text { To promote the } \\
\text { pluricentricity of } \\
\text { English and the } \\
\text { 'bilingual creativity' } \\
\text { of OCE-knowing } \\
\text { bilinguals }\end{array}$ & $\begin{array}{l}\text { Mainly description and } \\
\text { codification of new } \\
\text { Englishes and the } \\
\text { gaining of recognition as } \\
\text { an emergent paradigm, } \\
\text { through the process of } \\
\text { legitimization }\end{array}$ \\
\hline
\end{tabular}


Table 6. The ELF paradigmatic axioms

\begin{tabular}{|c|c|c|c|}
\hline Approaches & Exponents & Objectives & Research and practice \\
\hline $\begin{array}{l}\text { (ELT/EFL) } \\
\text { Focus: connectivity } \\
\text { and communication } \\
\text { minus the } \\
\text { linguacultural } \\
\text { aspects of IE } \\
\text { Bodies: IAWE, College } \\
\text { of World Englishes }\end{array}$ & $\begin{array}{l}\text { House (1999); } \\
\text { Seidlhofer (2001; } \\
\text { 2004; 2006); Jenkins } \\
\text { (2000; 2004; 2006); }\end{array}$ & $\begin{array}{l}\text { To promote a new concept } \\
\text { of English as a contact } \\
\text { language, the chosen } \\
\text { foreign language of } \\
\text { communication 'for } \\
\text { groups of English } \\
\text { speakers having } \\
\text { different first language } \\
\text { backgrounds' }\end{array}$ & $\begin{array}{l}\text { Definitions and } \\
\text { parameter setting } \\
\text { Description and } \\
\text { codification } \\
\text { Phonology } \\
\text { Lexico-grammar } \\
\text { Distinctive features of } \\
\text { ELF } \\
\text { Supra-features, e.g. } \\
\text { pragmatics }\end{array}$ \\
\hline
\end{tabular}

Owing to the transient and incipient nature of the interactions in English, ECE users have no stake in the indigenization or identity-marking processes of Outer Circle areas, where English is used in greater depth and over a larger range of functions. The emergence of new creative literature and new canons is an assumption in WE that ELF does not make.

Thus, in the three paradigms - although the language components of phonetics and phonology, syntax and semantics, and pragmatics are very much commonalities in the teaching and learning landscape - the polarities are different. IE is drawn towards a standard ideology; WE focuses on the importance of sociolinguistic realities; and the ELF concern is with connectivity in English but minus the linguacultural material that comes with the language.

In a quadrant analysis (Figure 1), we can recapitulate the main points of the foregoing discussion.

Quadrant 1, representing the IE position, has a NS starting point: native speakers (however defined) using English to communicate with other native speakers and with nonnative speakers. The monocentricity, or at most duocentricity, of English is paramount. A number of scholars have documented the colonial-celebratory position that 'trumpets the benefits of English' (Pennycook 2002: 218; Bailey and Görlach 1982; Phillipson 1992) based on a long tradition of 'glorifying the English language'. In the great Quirk-Kachru debate of the early 1990s, Kachru labeled Quirk's approach as deficit linguistics because the latter did not see the merit of teaching other than standard English to those who, in Quirk's words, 'paid good money to learn the language'. The standard language ideology in Q1 demands a compliant response - in teaching, learning, and testing.

Quadrant 2, on the other hand, along with Quadrant 4, represents the WE position of how a language of wider communication changes and adapts. WE has at its core the tenet that English is pluricentric, with many new Englishes showing hybrid forms as a result of a modern celebration of the English language - as a lingua franca with multiple identities, as one medium with multiple voices, and as a multiplicity of canons. This approach espoused by Kachru was labeled 'liberation linguistics' by Quirk. An identity ideology demands a contesting response in teaching, learning, and testing.

Q3, capturing the newest paradigm to emerge in the study of English as a lingua franca, focuses on ECE users trying to connect in the contact language English. As an evolving paradigm, ELF can be predicted to run two courses, one closer to the IE position of compliance in Q1 (establishing new standard forms for ELF interactions) and the other 


\begin{tabular}{|c|c|}
\hline Q1 & Q4 \\
\hline $\begin{array}{l}\text { NS } \rightarrow \leftarrow \text { NS } \quad \text { (Inner Circle to ICE) } \\
\text { NS } \rightarrow \leftarrow \text { NNS (Inner Circle to OCE, ECE) }\end{array}$ & $\begin{array}{l}\mathrm{NS} \rightarrow \leftarrow \mathrm{NS} \\
\mathrm{NS} \rightarrow \leftarrow \mathrm{NNS} \\
\mathrm{NNS} \rightarrow \leftarrow \mathrm{NNS}\end{array}$ \\
\hline IE: monocentricity of English & $\begin{array}{l}\text { (All three circles) } \\
\text { WE: pluricentricity of English }\end{array}$ \\
\hline $\begin{array}{l}\text { deficit linguistics } \\
\text { standard ideology (compliance) } \\
\text { colonial celebratory }\end{array}$ & $\begin{array}{l}\text { liberation linguistics } \\
\text { identity ideology (contestation) } \\
\text { modern celebratory }\end{array}$ \\
\hline Q2 & Q3 \\
\hline NNS $\rightarrow \leftarrow$ NNS (Expanding Circle) & NNS $\rightarrow \leftarrow$ NNS (Outer Circle to OCE, ECE) \\
\hline EFL/EFL: & ESL/EFL: \\
\hline ELF: 'contact' nature of English & WE: 'indigenized' nature of English \\
\hline
\end{tabular}

Figure 1. Quadrant analysis

closer to the WE contesting position of language change and adaptation. With a focus on this second possibility, scholars like Modiano (2004) and Canagarajah (2006) have recently emphasized the negotiation of the local in English as a lingua franca.

In other words, as demonstrated in Figure 2, going through the same layers of phonetics, phonology, syntax, semantics and pragmatics, the three paradigms are pulling towards quite different ends: in the case of IE, towards a standard language ideology, in WE, towards sociolinguistic realities, and in the case of ELF, towards connectivity in English minus the linguacultural material that comes with the language.

If we return to the aim of exploring whether 'lingua franca' as a theoretical concept applied by the different paradigms is congruent or incongruent, we will see that in the 


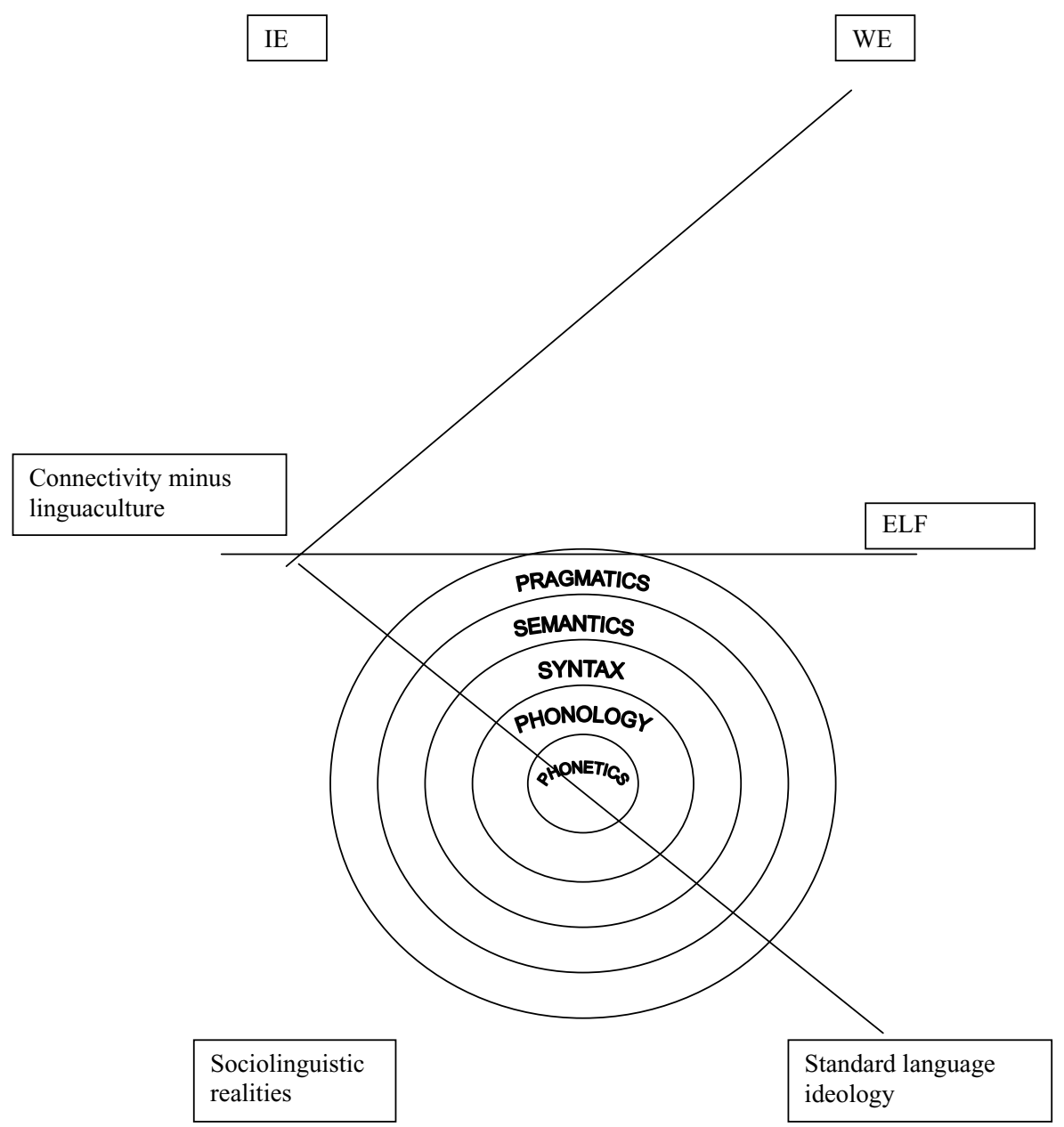

Figure 2. Orientations in IE, WE, and ELF paradigms

'sociolinguistic realities' orientation taken by WE and the 'standard language ideology' taken by IE there is a vast difference in terms of successfully managing the study of English with its current mobility and portability features. ELF does not clearly stand out as having an orientation that will successfully predict its enterprise of managing the study of English in the world.

In returning to the second aim of examining the discourses surrounding these labels, arguably the Kachruvian Outer Circle countries offer a vast potential for study. Singapore is a valuable case study because English is certainly the lingua franca in this multilingual nation, where English-knowing bilingualism over an entire population has led it to becoming an ascendant English-knowing bilingual community (Pakir 2003). Four decades of instilling English-knowing bilingualism in Singapore have resulted in the rise of an English-knowing bilingual community drawing from its local values and multilingual identities. An ascendant bilingual as defined by $\mathrm{Li}(2000)$ is 'someone whose ability to 
function in a second language is developing due to increased use'. If we go beyond the individual and look at their society, we begin to see that a whole community can shift over to ascendancy in English-knowingness, functioning more and more in the second language, but because of their collective association with their other languages and cultures, the issue of identity will remain a recurrent theme. Ascendant English-knowing bilingual communities offer a good site to study the emergence of what I have termed 'glocal English'.

A full decade ago, David Graddol (1997: 33) posited a view of two models of English as a lingua franca (as cited in Pakir 2001: 85). There was the traditional import-export model and the postmodern/globalized model. One major implication for the first model was that 'key intermediaries' (negotiators/interpreters with English language skills) provided the interface with local language speakers. This model hints at a static, clearly bounded situation where a standard - or at most two standards - of English existed, and the key intermediaries had to be given training in it/them. In the second model, all (or most) team members need English language skills. The second model hints at the modeling of language and culture in terms of flow: communication flow and counterflow, producing a tension between the global and the local. This tension between the local and the global resolves itself in the emergence of glocal English, one that is internationally oriented but locally appropriate. Global yet local, glocal English can be viewed as an international as well as national lingua franca.

The possibility of English playing a dual role as an international lingua franca (especially for the Outer Circle) and as a national lingua franca (especially in the Outer Circle), as seen in the Singapore case, reveals some gaps in the ELF or IE frameworks. Keeping in view all the cultural and pedagogical implications and paradigms described earlier, the Singapore case study manifests to the rest of the world that English can be negotiated for local identity. It can be open to the approaches offered by the IE and ELF paradigms, but as Kachru would ask: does IE or ELF provide any interesting insight for our better understanding of the contexts of institutionalized world Englishes? The issue of identity will remain in these contexts, even as the users of English move on to their ascendant English-knowing bilingualism. An apt example of this point regarding local identity, expressed in English as a lingua franca, is found in this example of 'glocal English' from Singapore (Leow 1995).

\author{
A POEM NOT TOO OBIANG \\ From fiddlesticks and By Jove \\ I pick my words to find \\ Alamak \\ Stirring spicily on my tongue - \\ Like the first bite \\ Of green chillies that sends \\ Tentative excitement \\ Popping out of their seeds \\ Why should I not drink \\ Teh tarik and discuss \\ Lee Tzu Pheng \\ (without putting them in italics) \\ among friends who read but
}


Tread on the trappings of blind

Milton and Shakepearean worship?

Like the prata man's

Flips and flaps of the dough

Taking shape with each dose

Of local flavour,

I look for my place

In a Singaporean life.

My place in the sun

Is certainly not too LC

For some others' meringue pies

And afternoon tea.

The issue of identity resonates in speakers of English who use English as a national lingua franca as well as an international one.

\section{SOME TENTATIVE CONCLUSIONS}

With a vast geography, a compressed history, and enjoying accelerative speed, English as a worldwide presence is not the same phenomenon everywhere. In fact, Crystal maintains:

It may well be the case that the English language has already grown to be independent of any form of social control. There may be a critical number or critical distribution of speakers ... beyond which it proves impossible for any single group of alliance to stop its growth, or even influence its future.... It may be that English, in some shape or form, will find itself in the service of the world community for ever. (1997: 139-40)

Returning to the questions posed at the beginning, I offer a quick summary and some very tentative conclusions. The English as Lingua Franca (ELF) paradigm focuses on modern-day connectivity mainly in the Expanding Circle of English-speaking countries (and seems to be, for the moment, European-driven). Proponents of ELF maintain that English as a language of communication in the Expanding Circle of English countries will not contain linguaculturae from the Inner Circle of English (as represented in discussions concerning International English or English as a native language). For ELF scholars, languages and cultures in the Expanding Circle develop in their own right, and will or may develop pluricentric Englishes but with an ELF core.

WE and ELF are similar in that they have four in common working axioms: emphasizing the pluricentricity of English, seeking variety recognition, accepting that language changes and adapts itself to new environments, and observing the discourse strategies of Englishknowing bilinguals. WE and ELF differ in that while WE includes all users of English in the three circles, ELF does not, choosing instead to focus on ECE users, who have no language in common because of their first other languages and thus choose English as the default language. Owing to the transient and incipient nature of the interactions in English, users in ECE have no stake in the indigenization or identity-marking processes of users in the OCE where English is used in greater depth and over a larger range of functions. The emergence of new creative literature and new canons is an assumption in WE that ELF does not make. 
I tentatively conclude that WE and ELF are similar in many ways but dissimilar in significant ones. The focus in WE is that of sociolinguistic realities, of the range and depth of English language use in Outer Circle countries especially. The focus in ELF/LFE is on finding the common features that serve to identity that variety of English which is used as a language of communication minus linguacultural minutiae.

Consideration of English as a lingua franca has raised serious issues concerning whose construct is the most appropriate to understand the new functions, values, and meanings of English in an increasingly globalized and interconnected world - that is, the cause and effect of the power of the language as communication. In the negotiation of English as a lingua franca against the backdrop of the universal presence of English in an interconnected world, the emphasis on linguistic and cultural hybridity and a critical approach cannot be stressed often enough (even as IE proponents emphasize the importance and necessity of a standard language ideology).

Retaining our indigenous cultures and languages(s) while reaping the benefits of large-scale integration via a language of wider communication is the challenge many of us will not doubt have to come to terms with in the years to come. (Modiano, 2004: 225, cited by Canagarajah, 2006:197)

\section{REFERENCES}

Bailey, Richard W., and Görlach, Manfred (eds.) (1982) English as a World Language. Ann Arbor: University of Michigan Press.

Bautista, Ma. Lourdes S. (1997) The lexicon of Philippine English. In Ma. Lourdes S. Bautista (ed.), English is an Asian Language: The Philippine Context (pp. 49-72). Sydney: Macquarie Library.

Bolton, Kingsley (2004) World Englishes. In Alan Davies and Catherine Elder (eds.), The Handbook of Applied Linguistics (pp. 367-96). Oxford: Blackwell.

Canagarajah, Suresh A. (2006) Negotiating the local in English as a lingua franca. Annual Review of Applied Linguistics 26, 197-218.

Crystal, David (1997) English as a Global Language. Cambridge: Cambridge University Press.

Firth, Alan (1996) The discursive accomplishment of normality: on 'lingua franca' English and conversation analysis. Journal of Pragmatics 26, 237-59.

Graddol, David (1997) The Future of English? London: British Council.

House, Juliane (1999) Misunderstanding in intercultural communication: interactions in English-as-lingua-franca and the myth of mutual intelligibility. In Claus Gnutzmann (ed.), Teaching and Learning English as a Global Language (pp. 73-89). Tubingen: Stauffenburg.

Jenkins, Jennifer (2000) The Phonology of English as an International Language. Oxford: Oxford University Press.

Jenkins, Jennifer (2004) ELF at the gate: the position of English as a lingua franca. In A. Pulverness (ed.), IATEFL 2004 Liverpool Conference Selections (pp. 33-42). Canterbury, UK: IATEFL.

Jenkins, Jennifer (2006) Current perspectives on teaching world Englishes and English as a lingua franca. TESOL Quarterly 40, 157-81.

Kachru, Braj B. (1982) South Asian English. In Bailey and Görlach (1982: 353-83).

Kachru, Braj B. (1983) The bilingual's creativity: discoursal and stylistic strategies in contact literatures in English. Studies in the Linguistic Sciences 13, 37-55.

Kachru, Braj B. (1986) The Alchemy of English: The Spread, Functions and Models of Non-native Englishes. Oxford: Pergamon.

Kachru, Braj B. (1996) English as lingua franca. In Hans Goebl, Peter H. Nelde, Zdenek Starý, and Wolfgang Wölck (eds.), Kontaktlinguistik, vol. 1 (pp. 906-13). Berlin: Mouton de Gruyter.

Leow, Jason (1995) A poem not too obiang. In Edwin Thumboo and Chee Lick Ho (eds.), Journeys: Words, Home and Nation: An Anthology of Singapore Poetry, 1984-1995 (p. 138). Singapore: UniPress.

Li, Wei (2000) Which English? Nativization of English and the negotiations of language choice in Southeast Asia. In E. Rudiger Ahrens, David Parker, Klaus Stierstorfer, and Kwok-Kan Tam (eds.), Anglophone Cultures in Southeast Asia (pp. 73-84). Heidelberg: Universitätsverlag.

Lowenberg, Peter (1984) English in the Malay archipelago: nativization and its functions in a sociolinguistic area. $\mathrm{PhD}$ dissertation, University of Illinois at Urbana-Champaign. 
Modiano, Marko (2004) Monoculturalization and language dissemination. Journal of Language, Identity, and Education 3, 215-27.

Modiano, Marko (2005) Cultural studies, foreign language teaching and language practices and the non-native speaker practitioner. In Enric Llurda (ed.), Non-native Language Teachers: Perceptions, Challenges, and Contributions to the Profession (pp. 25-43). Boston, MA: Springer.

Pakir, Anne (1992) English-knowing bilingualism in Singapore. In K. C. Ban, Anne Pakir, and C. K. Tong (eds.), Imagining Singapore (pp. 234-62). Singapore: Times Academic Press.

Pakir, Anne (1994) English in Singapore: the codification of competing norms. In S. Gopinathan, A. Pakir, W. K. Ho, and V. Saravanan (eds.), Language, Society and Education in Singapore: Issues and Trends. Singapore: Times Academic Press.

Pakir, Anne (1997) Standards and codification for world Englishes. In Larry E. Smith and Michael E. Forman (eds.), World Englishes 2000 (pp. 169-81). Honolulu: University of Hawai'i Press.

Pakir, Anne (2000) The development of English as a 'glocal' language: new concerns in the old saga of language teaching. In W. K. Ho and C. Ward (eds.), Language in the Global Context: Implications for the Language Classroom (pp. 14-31). Singapore: SEAMEO Regional Language Centre.

Pakir, Anne (2001) English as lingua franca: multiforms, multimedia, multi-disciplines. In Edwin Thumboo (ed.), The Three Circles of English (pp. 77-90). Singapore: Unipress.

Pakir, Anne (2003) Which English? The nativization of English and the negotiations of language choice in Southeast Asia. In Rudiger Ahrens, David Parker, Klaus Stierstorfer, and Kwok-Kan Tam (eds.), Anglophone Cultures in Southeast Asia: Appropriations, Continuities, Contexts (pp. 73-84). Heidelberg: University of Heidelberg Press.

Pennycook, Alistair (2002) Ruptures, departures and appropriations: postcolonial challenges to language development. In C. Villareal, L. R. Tope, and P. Jurilla (eds.), Ruptures and Departures: Language and Culture in Southeast Asia (pp. 212-41). Diliman: University of the Philippines.

Phillipson, Robert (1992) Linguistic Imperialism. Oxford: Oxford University Press.

Seidlhofer, Barbara (2001) Closing a conceptual gap: the case for a description of English as a lingua franca. International Journal of Applied Linguistics 11, 133-58.

Seidlhofer, Barbara (2004) Research perspectives on teaching English as a lingua franca. Annual Review of Applied Linguistics 24, 209-42.

Seidlhofer, Barbara (2006) English as a lingua franca in the Expanding Circle: what it isn't. In Rani Rubdy and Mario Saraceni (eds.), English in the World: Global Rules, Global Roles (pp. 40-50). London: Continuum.

Smith, Larry (1981) English for Cross-Cultural Communication. London: Macmillan.

Smith, Larry (1988) Language spread and issues of intelligibility. In Peter H. Lowenberg (ed.), 1987 Georgetown Round Table on Languages and Linguistics: Language Spread and Language Policy (pp. 265-82). Washington, DC: Georgetown University Press.

Trudgill, Peter, and Hannah, Jean (1995) International English: A Guide to Varieties of Standard English, 3rd edn. London: Edward Arnold. 